\title{
THE EFFECT OF EXERCISE INTENSITY ON CALF VOLUME AND THERMOREGULATORY RESPONSES DURING UPPER BODY EXERCISE
}

\begin{abstract}
During upper body exercise the vascular adaptations of the leg have been reported to play an important thermoregulatory role. This study examined the effect of exercise intensity on thermoregulation during upper body exercise. Nine healthy male participants undertook an incremental exercise test on an arm crank ergometer to determine peak power $\left(\mathrm{W}_{\text {peak }}\right)$. The participants performed four experimental trials involving 5 minutes of arm exercise at either $45,60,75$, or $90 \% \mathrm{~W}_{\text {peak }}\left(70 \mathrm{rev}\right.$. $\left.\mathrm{min}^{-1}\right)$ followed by 30 minutes of passive recovery. Aural and skin temperatures, upper arm and calf heat flow were recorded. Calf volume was measured during exercise using plethysmography. During exercise at $45,60,75$ and $90 \% \mathrm{~W}_{\text {peak }}$ calf volume decreased $(\mathrm{P}<0.05)$ by $-0.7 \pm 0.8,-1.4 \pm 0.9,-1.2 \pm 0.6$ and $-1.6 \pm 0.7 \%$ respectively. Differences were observed between 45 and $60 \% \mathrm{~W}_{\text {peak }}$, and 45 and $90 \% \mathrm{~W}_{\text {peak }}(\mathrm{P}<0.05)$. The results of this study suggest a redistribution of blood from the relatively inactive lower body during arm exercise of intensities up to $60 \% \mathrm{~W}_{\text {peak }}$ after which point calf volume does not significantly decrease further. Therefore, the redistribution of blood from the inactive lower body does not produce a similar intensity dependent response to visceral blood flow during lower body exercise.
\end{abstract}

Keywords: ARM CRANK ERGOMETRY / BLOOD FLOW / CALF TEMPERATURE / THERMOREGULATION / EXERCISE INTENSITY

\section{INTRODUCTION}

During lower body exercise of moderate intensity in cool conditions skin blood flow increases (Johnson and Rowell, 1975), this in turn increases the thermal gradient between the skin and the atmosphere. An increased gradient provides heat for convection, radiation and evaporation of sweat enabling an improved heat exchange (Rowell, 1974). In contrast during upper body exercise in cool conditions calf volume has been demonstrated to decrease (Hopman, Verheifen \& Binkhorst, 1993) suggesting arterial blood flow to the calf decreases. This is supported by a decrease in calf skin temperature during prolonged upper body exercise (Price and Camp- bell, 1997, 2002). It has been suggested therefore that blood flow to the calf is being redistributed to the active upper body during arm exercise (Hopman, Verheifen \& Binkhorst, 1993). This redistribution of blood has been demonstrated to occur during lower body exercise from inactive tissue to augment cardiac output and supply the exercising muscles with blood (Ho et al., 1997; Sawka, 1986; Ahlborg \& Felig, 1982). Consequently, the active muscles receive a greater percentage of the cardiac output whereas the viscera receive less (Sawka, 1986; Rowell, Blackmon \& Bruce, 1964; Rowell et al., 1965). 
During lower body exercise forearm skin blood flow, which is often used to represent whole body cutaneous blood flow (Johnson \& Rowell, 1975), has been observed to increase linearly with oesophageal temperature (Smolander et al., 1987; Nadel et al.,1979) up to an exercise intensity of $80 \% \mathrm{VO}_{2 \max }$. After this point the relationship is attenuated with no further increases in skin blood flow (Smolander et al., 1987). The same relationship has not been found for upper body exercise and lower body responses. In particular research has found a decrease in calf volume (representing skin, muscle and bone blood flow) during $10 \mathrm{~min}$ of upper body exercise at $50 \%$ $\mathrm{W}_{\text {peak }}$ suggesting a decrease in calf blood flow (Hopman, Verheifen \& Binkhorst, 1993). However, little is known regarding changes in calf volume at a range of exercise intensities and potential skin blood flow responses during upper body exercise. Blood pooling in the lower body could potentially cause thermoregulatory and cardiovascular stability problems during upper body exercise. As exercise intensity increases and the demand for increased blood flow at the active muscle and skin occurs, a greater redistribution of blood from the inactive muscles will be required. If blood pooling occurs in the lower body this could potentially cause an increased thermal strain on the body. Consequently, the vascular adaptations of the leg during upper body exercise have been suggested to play an important physiological and, more specifically, thermoregulatory role during upper body exercise, but has yet to be fully examined (Price \& Campbell, 1997).

During lower body exercise, changes in visceral blood flow are intensity dependent (Rowell, 1974) and it is possible that the reported decreases in calf volume may also exhibit the same intensity dependent response. Establishing the thermoregulatory responses in the lower body of able bodied individuals during upper body exercise at different intensities of exercise will help establish a thermoregulatory model that could assist in future exercise recommendations for individuals with for example spinal cord injuries or Multiple Sclerosis. Therefore, the principal aim of this study was to examine the effect of exercise intensity on calf volume changes during upper body exercise in order to examine the redistribution of blood during upper body exercise. It was hypothesised that as exercise intensity increased calf volume would decrease.

\section{METHOD}

\section{Participants}

Nine male participants (Mean \pm s age $22.9 \pm 3.6$ yrs, weight $78.4 \pm 13.7 \mathrm{~kg}$ ) generally but not specifically upper body trained, volunteered to participate in the study. University Ethics Committee approval for the study's experimental procedures was obtained along with written informed consent and followed the principles outlined in the Declaration of Helsinki.

\section{Preliminary Tests}

Participants attended the laboratory on five separate occasions. On the first visit, participants performed an incremental exercise test using an electronically braked arm crank ergometer (Lode, Angio, Groningen, the Netherlands), to determine peak oxygen uptake $\left(\dot{\mathrm{V}} \mathrm{O}_{2 \text { peak }}\right)$ and peak power output $\left(\mathrm{W}_{\text {peak }}\right)$. The latter was used to determine the exercise intensity for each subsequent experimental trial. Following a ten minute cool down, participants were familiarised with the four different exercise intensities, which were to be undertaken in the following four visits.

Each subject's $\dot{\mathrm{V}} \mathrm{O}_{2 \text { peak }}$ was determined using a discontinuous incremental exercise protocol (Smith, Price \& Doherty, 2001). Participants sat with their shoulder joint in line with the crank shaft of the ergometer. Their feet were positioned flat on the floor in metal cups to ensure the knee joint was at $90^{\circ}$. The protocol consisted of four, four-minute submaximal exercise stages $(30,50,70$, and $90 \mathrm{~W}$ respectively) with two minutes rest between stages. Subjects were required to maintain a cadence of 70 rev. $\mathrm{min}^{-1}$ throughout exercise. After the final four minute stage and rest period, the protocol increased by $20 \mathrm{~W}$ every two minutes from $110 \mathrm{~W}$ until volitional fatigue, or when participants were unable to maintain $70 \mathrm{rev}$. $\mathrm{min}^{-1}$. Expired gas (Metamax 3B, Leipzig, Germany) and heart rate (HR; Polar Accurex Plus, Kempele, Finland) were continually monitored.

\section{Submaximal Trials}

All exercise trials were performed at an ambient temperature of $20.5 \pm 1.4^{\circ} \mathrm{C}$ and $63.8 \pm 5.8 \%$ humidity. Participants arrived at the laboratory after fasting for two hours and abstaining from strenuous exercise during the previous 24 hours. The study was 
conducted as a cross-over design. Each subject was tested on four separate occasions with at least three days separating each trial. The trials consisted of 5 minutes of arm exercise at either $45,60,75$ or $90 \%$ of $\mathrm{W}_{\text {peak }}$, followed by 30 minutes of passive recovery.

On arrival at the laboratory, body mass was recorded using a balance beam scale (Seca, Hamburg, Germany). Participants wore shorts, socks, and training shoes and rested for 15 minutes while thermistors and sensors were attached. Aural and skin thermistors were continuously recorded via a data logger (Squirrel 1020 series, Cambridge, UK). Aural temperature was measured by an aural thermistor (Grant, Cambridge, UK) inserted into the subject's auditory canal and securely taped into position and insulated with cotton wool. Skin thermistors (Grant, Cambridge, UK) were attached to standard anatomical landmarks for the upper arm, back, chest, thigh, and calf. An additional thermistor was applied to the second toe on the right foot with the shoe and sock replaced. Thermistors were attached to the skin using strips of water permeable tape (3M Transpore, Loughborough, UK). Mean skin temperature $\left(\mathrm{T}_{\mathrm{ms}}\right)$ was calculated using the equation of Ramanathan (1964) where: $\mathrm{T}_{\mathrm{ms}}=0.3\left(\mathrm{~T}_{\text {chest }}\right)+0.3\left(\mathrm{~T}_{\text {upper arm }}\right)+$ $0.2\left(\mathrm{~T}_{\text {calf }}\right)+0.2\left(\mathrm{~T}_{\text {thigh }}\right)$. Heat flow was measured at the calf and the upper arm using heat flow sensors (Data Harvest Easy Sense Advanced, Bedfordshire, UK) and was recorded continuously. Sensors were attached adjacent to the skin thermistors on the calf and upper arm and were attached using water permeable tape according to the manufacturer's guidelines.

During each submaximal trial expired gas was continuously analysed. Baseline data for all measures were obtained during the seated rest for five minutes prior to exercise and a resting capillary blood sample $(80 \mu 1)$ taken from the earlobe for measurement of blood lactate (Analox GM7, London, UK). Strain gauge plethysmography was employed to measure relative volume changes of the calf during arm exercise. Lower leg blood flow was measured at rest using venous occlusion plethysmography and standard procedures (Hopman, Verheifen \& Binkhorst, 1993). The strain gauge plethysmograph (Hokanson EC6,
Bellevue, USA) consisted of two mercury filled tubes of silicon rubber, positioned around the thickest part of the left calf and taped into position. A contoured blood pressure cuff was placed on the left thigh, just above the knee, which was connected to a rapid cuff inflator (Hokanson E20, Bellevue, USA) set to inflate to $50 \mathrm{mmHg}$ for five seconds and deflate for eight seconds. The plethysmograph was connected to a personal computer via Powerlab (AD Instruments, Chalgrove, UK) and online recordings displayed through Chart4windows. An average of three inflations was used to determine blood flow at each time point.

Participants performed arm crank exercise for 5 minutes at 70 rev. $\mathrm{min}^{-1}$ at the randomly assigned exercise intensity. Heat flow and skin temperatures were recorded every minute during and on the cessation of exercise. Changes in calf volume from rest were recorded throughout exercise. $\mathrm{RPE}_{\text {central }}$ and $\mathrm{RPE}_{\text {local }}$ were recorded $30 \mathrm{~s}$ before the cessation of exercise. Oxygen uptake $\left(\dot{\mathrm{V}} \mathrm{O}_{2}\right)$, minute ventilation (VE) and respiratory exchange ratio (RER) were averaged over the last 30 s of each minute during exercise and at five minute intervals during 30 minutes of passive recovery. Blood flow was recorded at rest and at the cessation of exercise. Immediately post exercise a further capillary blood sample was taken from the earlobe for the measurement of blood lactate. Participants then remained seated for $30 \mathrm{~min}-$ utes of recovery. Heat flow, blood flow, aural and skin temperatures were recorded every 5 minutes of passive recovery. Body mass was recorded pre and post exercise to calculate sweat losses.

\section{Statistical Analysis}

All data were analysed via Minitab version 14.0. Data were analysed by Two-Way Analysis of Variance (time $\mathrm{x}$ intensity) with repeated measures. Where significance was obtained, Tukey post hoc was performed. Where appropriate Pearson's correlation was performed to investigate non-causal relationships between variables e.g. blood lactate verse RPE. Data are represented as mean \pm SEM in figures, and mean $\pm \mathrm{s}$ in tables. Significance was taken as $\mathrm{P}<0.05$. 


\section{RESULTS}

\section{Preliminary Tests}

The peak physiological responses obtained during the incremental test for $\dot{\mathrm{V}} \mathrm{O}_{\text {2peak }}$ are shown in Table 1.

Table 1: The mean $( \pm \mathrm{s})$ physiological responses obtained during the incremental $\dot{\mathrm{V}} \mathrm{O}_{\text {2peak }}$ test $(\mathrm{n}=9)$

\begin{tabular}{lc}
\hline & Mean ( \pm SD) \\
\hline$\dot{\mathrm{V}} \mathrm{O}_{2 \text { peak }}\left(1 . \mathrm{min}^{-1}\right)$ & $2.21( \pm 0.59)$ \\
$\dot{\mathrm{V}} \mathrm{O}_{2 \text { peak }}\left(\mathrm{ml}^{\mathrm{k}} \mathrm{kg}^{-1} \cdot \mathrm{min}^{-1}\right)$ & $28.6( \pm 7.1)$ \\
$\mathrm{HR}_{\text {peak }}\left(\right.$ beats. $\left.\mathrm{min}^{-1}\right)$ & $184( \pm 12)$ \\
$\mathrm{W}_{\text {peak }}(\mathrm{W})$ & $124( \pm 24)$ \\
$\mathrm{E}(1 . \mathrm{min}-1)$ & $73.9( \pm 16.7)$ \\
$\mathrm{Bla}_{\text {peak }}\left(\mathrm{mmol} . \mathrm{l}^{-1}\right)$ & $7.33( \pm 1.34)$ \\
$\mathrm{Respiratory} \mathrm{Exchange} \mathrm{Ratio}$ & $1.17( \pm 0.09)$ \\
$\mathrm{RPE}_{\text {central }}($ Borg Scale $)$ & $18( \pm 2)$ \\
$\mathrm{RPE}_{\text {local }}($ Borg Scale $)$ & $19( \pm 1)$ \\
\hline
\end{tabular}

\section{Physiological responses during exercise and} passive recovery

The physiological responses at the cessation of each submaximal arm exercise trial are shown in Table 2. A difference between exercise intensities was observed for both $\mathrm{HR}$ and $\dot{\mathrm{V}} \mathrm{O}_{2}$ during exercise and recovery (main effect; $P<0.05$ ). During passive re- covery, HR decreased but remained higher $(P<0.01)$ than rest in all but the $45 \% \mathrm{~W}_{\text {peak }}$ trial. Blood lactate increased linearly with exercise intensity $(P<0.05)$. Body mass decreased in all trials $(-0.1 \pm 0.1,-0.2$ $\pm 0.1,-0.1 \pm 0.1$ and $-0.1 \pm 0.1 \mathrm{~kg}$ for $45,60,75$ and $90 \% \mathrm{~W}_{\text {peak }}$ respectively) with no significant differences between the trials $(P>0.05)$.

Table 2 Mean $( \pm \mathrm{s})$ physiological responses at the cessation of arm exercise during each submaximal trial $(\mathrm{n}=9)$

\begin{tabular}{|c|c|c|c|c|c|}
\hline$\% \mathrm{~W}_{\text {peak }}$ & $\underset{\left(1 . \mathrm{min}^{-1}\right)}{\dot{\mathrm{V}} \mathbf{O}_{2}}$ & $\begin{array}{l}\text { Heart Rate (beats. } \\
\qquad \text { min }^{-1} \text { ) }\end{array}$ & $\begin{array}{l}\text { Blood lactate } \\
\qquad\left(\mathrm{mmol.}^{-1}\right)\end{array}$ & $\begin{array}{c}\mathrm{RPE}_{\text {entral }} \\
\text { (Borg Scale) }\end{array}$ & $\begin{array}{c}\mathbf{R P E}_{\text {local }} \\
\text { (Borg Scale) }\end{array}$ \\
\hline $45 \%$ & $1.16 \pm 0.15 *$ & $112 \pm 12 *$ & $3.0 \pm 0.6 *$ & $10 \pm 1 *$ & $11 \pm 2 *$ \\
\hline $60 \%$ & $1.46 \pm 0.21 *$ & $128 \pm 10 *$ & $5.0 \pm 1.2 *$ & $12 \pm 1 *$ & $14 \pm 1 *$ \\
\hline $75 \%$ & $1.72 \pm 0.31 *$ & $154 \pm 12 *$ & $6.7 \pm 0.8 *$ & $14 \pm 1 *$ & $15 \pm 1 *$ \\
\hline $90 \%$ & $2.09 \pm 0.49 *$ & $170 \pm 18 *$ & $8.1 \pm 1.0 *$ & $16 \pm 1 *$ & $18 \pm 2 *$ \\
\hline
\end{tabular}

*Significant $(\mathrm{P}<0.05)$ main effect between exercise intensities. 


\section{Aural Temperature during Exercise and Passive Recovery}

A main effect for exercise intensity was observed for aural temperature $(P<0.05)$. Post hoc analysis revealed differences between 45 and $90 \%$ $\mathrm{W}_{\text {peak }}$ trials and, 60 and $90 \% \mathrm{~W}_{\text {peak }}$ trials. At the end of exercise in all trials aural temperature had decreased from resting values by $-0.04 \pm 0.21,-0.03 \pm 0.20,-0.13$ \pm 0.08 and $-0.14 \pm 0.24^{\circ} \mathrm{C}$ for $45,60,75$ and $90 \%$ respectively.

\section{Upper Body Skin Temperatures during Exercise and Passive Recovery}

Upper arm skin temperature initially decreased during the first minute of exercise $(P<0.05$; Figure 1).
Immediately post exercise upper arm skin temperature increased for all trials $(P<0.05$; main effect for time). There was a main effect for exercise intensity with a greater increase in temperature occurring during the higher intensity trials $\left(75\right.$ and $90 \% \mathrm{~W}_{\text {peak }}$ ) when compared to the lower intensity trials $\left(45\right.$ and $\left.60 \% \mathrm{~W}_{\text {peak }}\right)$. A main effect for time was observed $(P<0.05)$ for chest temperature which decreased during exercise followed by an increase post exercise for all trials. There was no difference between exercise intensities for chest temperature $(P>0.05)$. Back skin temperature remained relatively constant throughout exercise and passive recovery for each exercise intensity $(P>0.05)$.

Figure 1 Mean $( \pm \mathrm{SEM})$ relative changes in upper arm skin temperature during each exercise trial at 45,60 , 75 and $90 \% \mathrm{~W}_{\text {peak }}$ and passive recovery $(\mathrm{n}=9)$. EX denotes exercise period.

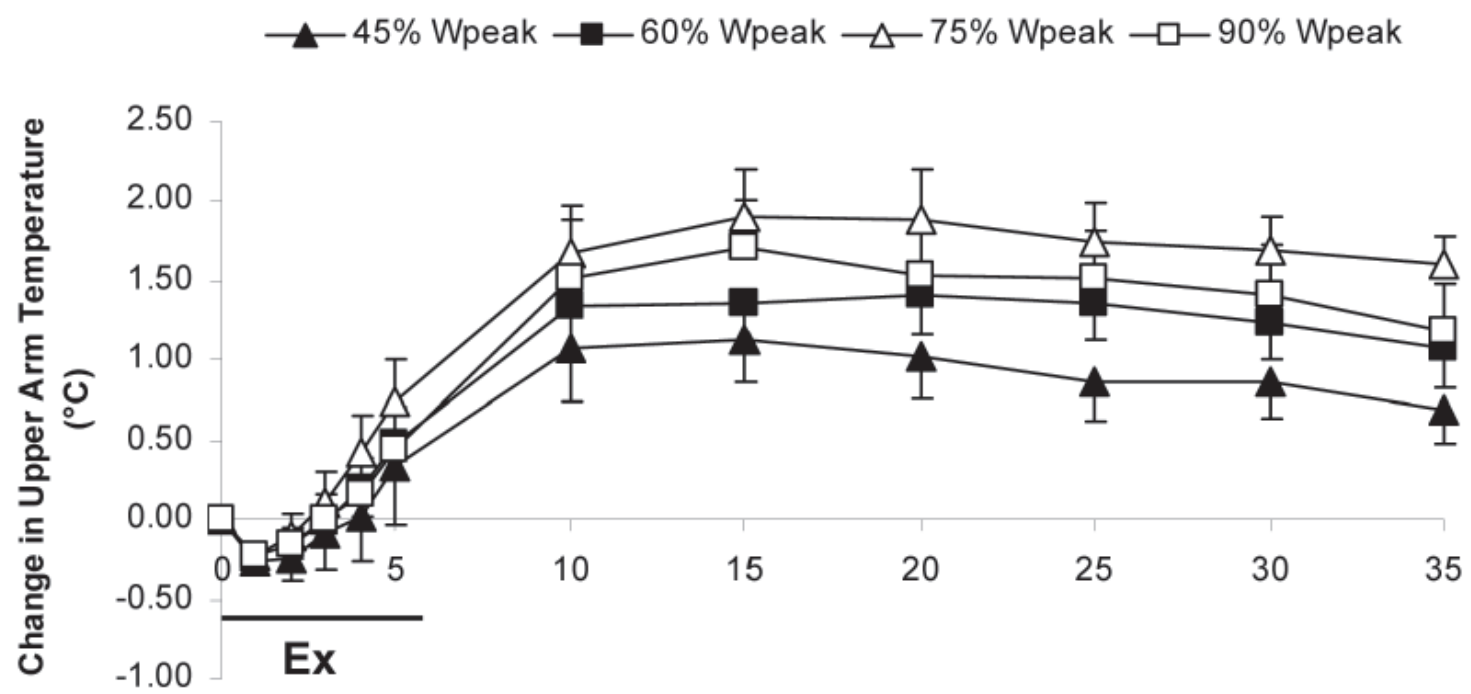

Time (min)

\section{Lower Body Skin Temperatures during Exercise and Passive Recovery}

Thigh skin temperature decreased during exercise and passive recovery (main effect for time $P<0.05)$. Differences were observed between 60 and $75 \% \mathrm{~W}_{\text {peak }}$ trials, 60 and $90 \% \mathrm{~W}_{\text {peak }}$ trials (main effect for intensity; $P<0.05$ ). During exercise calf temperature remained constant however, during recovery calf temperature decreased in all trials $(P<0.05)$, with a greater decrease in temperature during recovery from the higher exercise intensities $\left(75\right.$ and $90 \% \mathrm{~W}_{\text {peak }}$;
Figure 2) when compared to the lower intensities (main effect for intensity; $P<0.05$ ). Calf skin temperature decreased by $1.0 \pm 0.6,0.9 \pm 0.3,1.0 \pm 0.3$, and $1.0 \pm 0.5^{\circ} \mathrm{C}$ during $45,60,75$ and $90 \% \mathrm{~W}_{\text {peak }}$ after 30 minutes of recovery, respectively $(P<0.05)$. Toe temperature remained constant throughout exercise, and immediately increased during passive recovery $(P<0.05)$. A significant difference between exercise intensities was observed between 45 and $60 \% \mathrm{~W}_{\text {peak }}$, 60 and $75 \% \mathrm{~W}_{\text {peak }}$, and 60 and $90 \% \mathrm{~W}_{\text {peak }}$. 
Figure 2 Mean $( \pm \mathrm{SEM})$ relative changes in calf skin temperatures during each exercise trial at 45, 60, 75 and $90 \% \mathrm{~W}_{\text {peak }}$ and passive recovery $(\mathrm{n}=9)$. EX denotes exercise period.

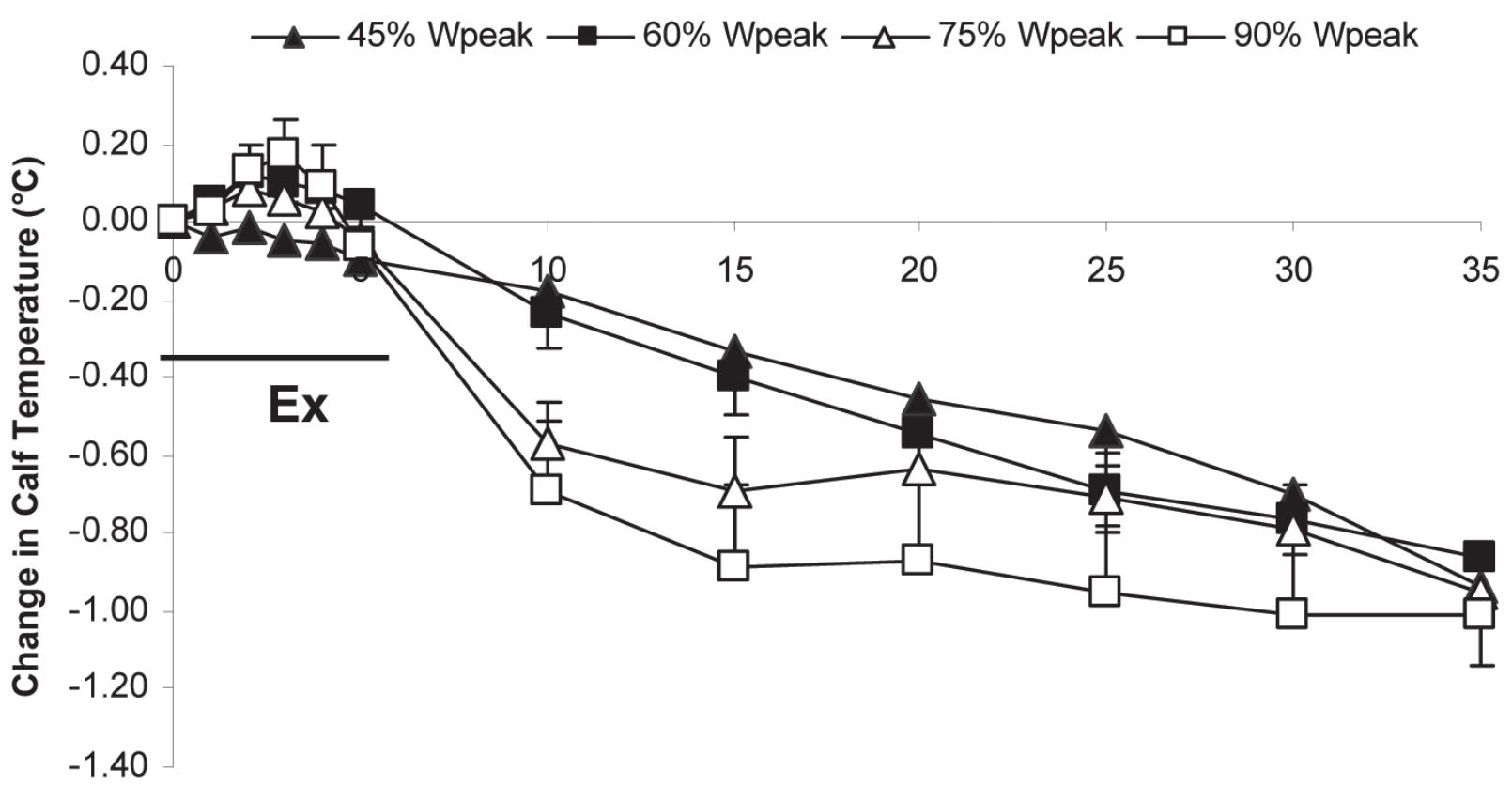

Time (min)

\section{Mean Skin Temperature}

Mean skin temperatures obtained in the present study were similar at rest $(30.6 \pm 0.9,30.6 \pm 0.5$, $30.3 \pm 1.1$ and $30.5 \pm 1.1^{\circ} \mathrm{C}$ for $45,60,75$ and $90 \%$ $\mathrm{W}_{\text {peak }}$ respectively) when compared to those at the end of exercise in all trials $(30.5 \pm 0.9,30.6 \pm 0.8,30.4 \pm 1.4$ and $30.2 \pm 1.5^{\circ} \mathrm{C}$ respectively).

\section{Heat Flow during Exercise and Passive Recovery}

Heat flow from the upper arm increased from rest during the first minute of exercise (increased by $27 \pm 13,21 \pm 7,26 \pm 13$ and $29 \pm 16 \mathrm{~W} \cdot \mathrm{m}^{-2}$ for 45,60 , 75 and $90 \% \mathrm{~W}_{\text {peak }}$, respectively; $P<0.05$; Figure $3 \mathrm{a}$ ).
However, there was a tendency for further increases in heat flow during exercise but not significant in any trial. On the cessation of exercise heat flow decreased $(P<0.05)$ and remained constant throughout passive recovery. Heat flow during exercise and recovery at $90 \% \mathrm{~W}_{\text {peak }}$ was greater than the other three intensities $(P<0.05)$. No further differences were noted between trials. In contrast to the upper arm, heat flow from the calf remained constant throughout exercise and passive recovery at all exercise intensities $(P>0.05$; Figure $3 b)$. However, heat flow was lower during the $45 \% \mathrm{~W}_{\text {peak }}$ when compared to the other three intensities at rest and throughout both exercise and passive recovery (main effect for intensity; $P<0.05$ ). 
Figure 3 Mean $\left( \pm\right.$ SEM) heat flow measurements for a) upper arm and b) calf at $45,60,75$ and $90 \% \mathrm{~W}_{\text {peak }}$ $(n=9)$.
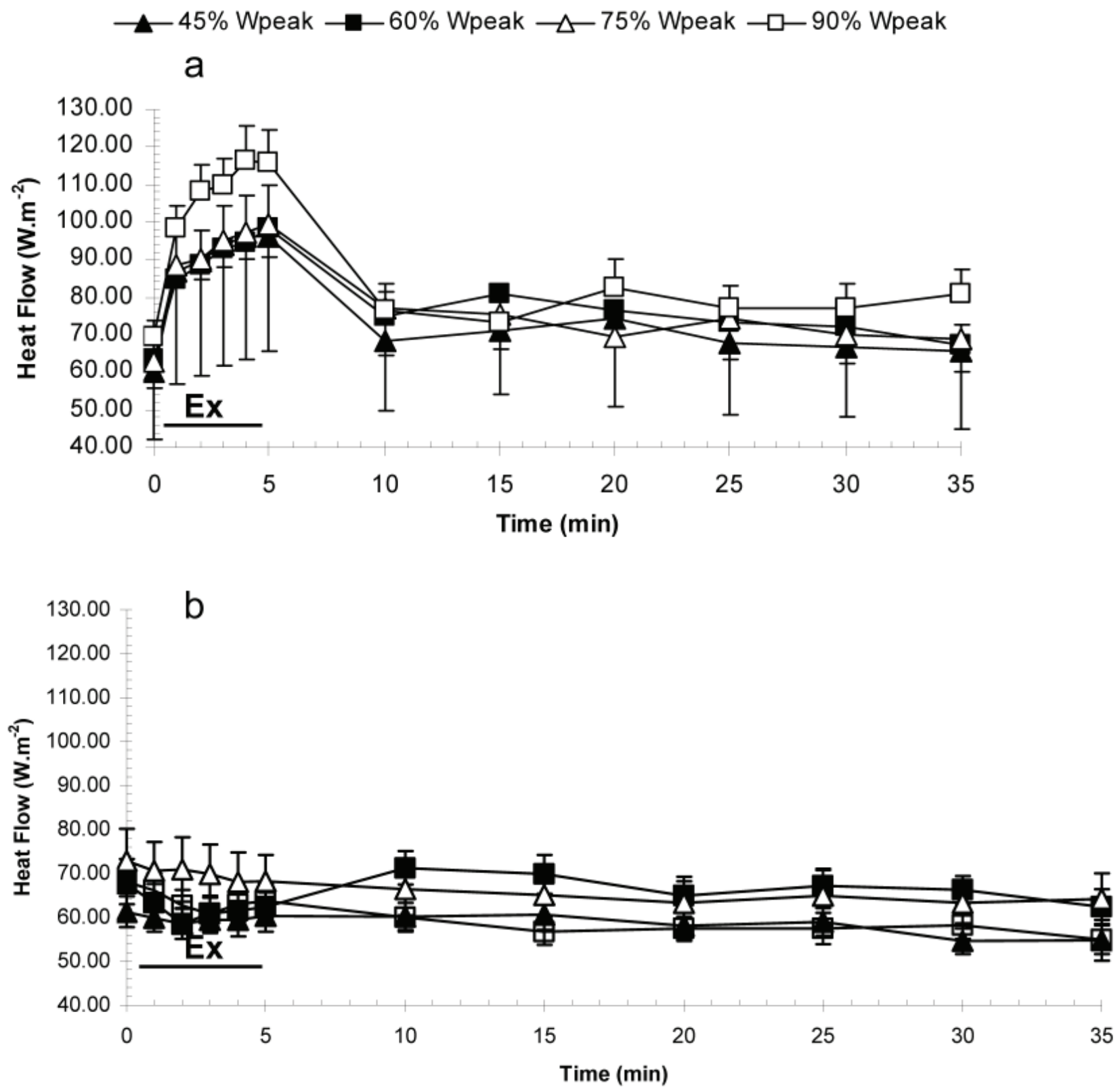

\section{Calf Volume and Blood Flow during Exercise and Passive Recovery}

When compared to rest, calf volume decreased $(P<0.05)$ during exercise at each exercise intensity $(-0.7 \pm 0.8,-1.4 \pm 0.9,-1.2 \pm 0.6$, and $-1.6 \pm 0.7 \%$ respectively; Figure 4). Differences were observed between $45 \%$ and $60 \% \mathrm{~W}_{\text {peak }}$, and 45 and $90 \% \mathrm{~W}_{\text {peak }}$ $(\mathrm{P}<0.05)$. Calf volume returned to baseline within five minutes of passive recovery in all trials. Blood flow values were greatest at the end of exercise when compared to rest $(1.32 \pm 0.52,1.91 \pm 0.58,2.11 \pm 0.81$ and $\quad 1.76 \pm 0.68 \mathrm{ml}^{\mathrm{min}} \mathrm{m}^{-1} .100 \mathrm{ml}^{-1}$ respectively, $P<0.05)$ returning to baseline during passive recovery $(1.32 \pm 0.36,1.36 \pm 0.47,1.63 \pm 0.74$ and $1.38 \pm 0.55$ $\mathrm{ml} \cdot \mathrm{min}^{-1} .100 \mathrm{ml}^{-1}$, respectively) for each trial. Examining the blood flow on an inflation by inflation basis immediately at the cessation of exercise the first measurement of calf blood flow was significantly greater than the second and third measurements (main ef- 
fect for time; $P<0.05)$. There was also a main effect for trial, with blood flow being significantly lower during the $45 \% \mathrm{~W}_{\text {peak }}$ trial compared to the other tri- als $(P<0.05)$, with no other differences occurring $(P>0.05)$.

Figure 4 Percentage change in calf volume during exercise at each exercise intensity ( $m e a n \pm S E M ; n=9$ ). *Shows significant difference $(\mathrm{P}<0.05)$ from $45 \%$ intensity.

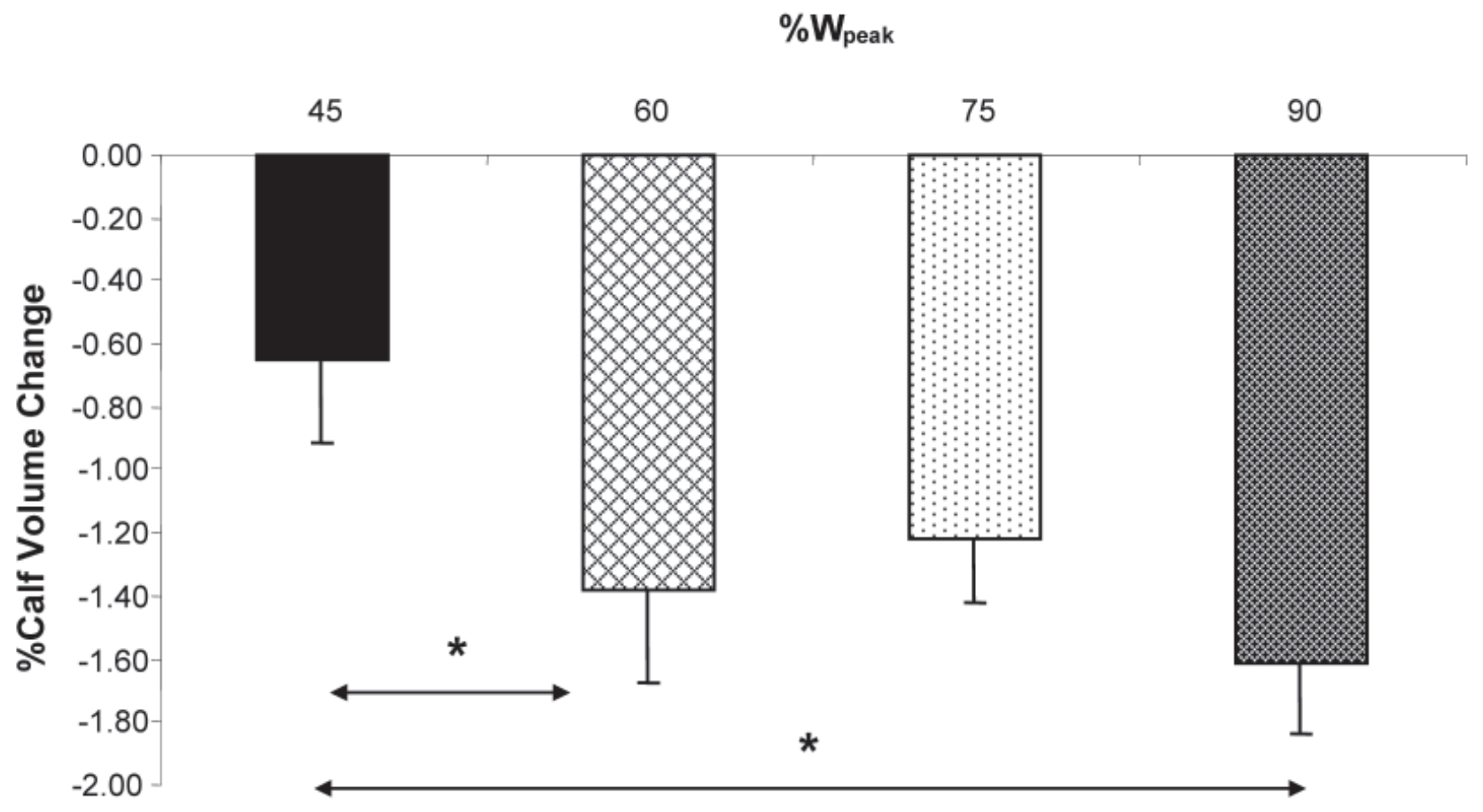

\section{DISCUSSION}

The principal aim of the study was to determine the effects of exercise intensity on calf volume using strain gauge plethysmography as a means of examining the redistribution of blood during arm exercise. The main finding of the study was a decrease in calf volume during arm exercise of intensities up to $60 \% \mathrm{~W}_{\text {peak }}$ after which point calf volume did not significantly decrease further. This decrease in calf volume was accompanied by an increase in calf blood flow from rest to the end of exercise.

\section{Upper Body Thermoregulatory Responses}

During the first 5 minutes of passive recovery there was a significant increase in arm skin temperature in all trials due to decreased convective air currents and resultant decrease in arm heat flow. The 75 and $90 \% \mathrm{~W}_{\text {peak }}$ trials demonstrated greater increases in arm skin temperature, most likely due to the greater metabolic heat production than 40 and $60 \% \mathrm{~W}_{\text {pea }}$ trials. Consequently, greater local heat storage is likely to have occurred as changes in convective air currents would have been the same for each trial (i.e. all exercise performed at the same movement speed; 70rev. $\mathrm{min}^{-1}$ ). Conversely, the initial decrease in arm temperature during exercise was probably due to increased heat flow as a result of convection current generation on the initiation of movement (Mitchell, 1977).

Sawka et al., (1984) suggested that heat flow values were representative of skin conductance and therefore provide a relative index of cutaneous blood flow. Therefore, in the present study blood flow to the upper arm must have increased based on the increased heat flow. Absolute arm heat flow was similar for the 45, 60 and $75 \%$ trials but greater for the $90 \%$ trial suggesting a greater increase in skin blood flow at the higher exercise intensity. This may repre- 
sent the exercise intensity where direct heat transfer from the contracting muscle was greater. Indeed, if heat flow does represent skin blood flow (Sawka et al., 1984) then this would have allowed greater heat transfer from the upperarm to the environment in the $90 \%$ trial resulting in a similar absolute increase in skin temperature to the other trials.

\section{Lower Body Thermoregulatory Respons}

A decrease in calf volume was observed during all exercise intensities, however, after $60 \% \mathrm{~W}_{\text {peak }}$ no further decreases were observed. Hopman, Verheifen \& Binkhorst (1993) measured calf volume during 10 min of arm exercise at $50 \% \mathrm{~W}_{\text {max }}$ and observed a decrease in volume of $0.1 \%$ per minute at $5 \mathrm{~min}$ of exercise, which is the same rate of decrease in limb volume per minute as during the $45 \% \mathrm{~W}_{\text {peak }}$ trial in the present study. However, the present study has expanded upon these data in observing that the decrease in calf volume was not linear with exercise intensity, and therefore does not express the same intensity dependent decrease as visceral blood flow. This would most likely be due to any further decrease in leg blood flow with higher exercise intensities resulting in a relatively small flow rate which may compromise oxygen delivery to the lower limb. The most likely role of calf vasoconstriction during the initial stages of exercise is to help maintain cardiovascular stability.

In contrast to the present study's results and Hopman, Verheifen \& Binkhorst (1993), Theisen et al., (2001a, 2001b) observed that during arm exercise at $50 \% \mathrm{~W}_{\text {peak }}$ and $80 \% \mathrm{~W}_{\text {peak }}$ skin blood flow of the calf increased during exercise. These authors measured skin blood flow using Laser Doppler Flowmetry which only measures blood flow up to $1.5 \mathrm{~mm}$ below the skin (Johnson et al., 1984). +Therefore, the decrease in calf volume observed in the present study using plethysmography, may be due to a reduction in predominantly muscle blood flow rather than blood flow to the superficial skin layers (Saumet et al., 1988). This is supported by Seals (1989) who suggested that during handgrip exercise skin blood flow increases while muscle blood flow to the calf decreases.

Although there was a decrease in calf volume during exercise, there was no significant difference in calf temperature or calf heat flow. Previous research (Price \& Campbell, 1997) observed a decrease in calf temperature during exercise, but as previously mentioned the exercise duration was considerably longer (60-90 $\mathrm{min}$ ). It was suggested in this instance that the decrease in calf temperature during prolonged arm exercise at constant exercise intensity $\left(60 \% \mathrm{~V} \mathrm{O}_{2 \text { peak }}\right)$ and environmental temperature was due to decreased blood flow to the calf. Since the calf is relatively metabolically inactive during upper body exercise, longer durations of exercise may be required for significant changes in calf skin temperature to occur due to reduced blood flow and changes in thermal state. Therefore examining the relationship between calf volume and skin temperature over greater durations of exercise would contribute to our understanding of calf blood flow and skin temperature relationship.

Calf volume immediately began to return towards baseline once exercise ceased suggesting blood flow to the muscle was returning. This could be potentially explained by a rapid vasodilation at the calf occurring immediately at the cessation of exercise causing a rapid increase in blood flow (hyperaemia) to the calf. During the present study calf volume was observed to decrease during exercise which was most likely due to increased muscle sympathetic nerve activity (Saito et al. 1993) causing vasoconstriction in the calf. As soon as exercise ceased a rapid vasodilation occurred causing a rapid increase in calf blood flow as blood returned to the calf. This is demonstrated by the fact that blood flow was greatest on the first measurement post exercise compared to the second and third measurements however this only occurred during the 75 and $90 \% \mathrm{~W}_{\text {peak }}$ trials. Muscle sympathetic nerve activity (MSNA) is exercise dependent (Saito et al. 1993) therefore the MSNA was only sufficient during exercise in the 75 and $90 \% \mathrm{~W}_{\text {Peak }}$ trials to cause this rapid hyperaemia as exercise ended. Blood flow decreased towards baseline values for the remainder of passive recovery, following this initial increase.

Several studies have determined the average volume of the calf and results have varied between 1.7 - 3.4L (Hargens, 1983; Convertino et al. 1989; Moore \& Thornton, 1987). Therefore using these approximate volumes the amount of blood being redirected away from the calf during upper body exercise in this study can be estimated. Calf volume decreased between $0.7-1.6 \%$ during exercise in all studies which equates to about $12-54 \mathrm{ml}$ of blood being redirected away from the calf. Therefore, the results 
demonstrate that the lower body appears to have a small contribution not only to thermoregulation but also to cardiovascular stability.

The decrease in calf skin temperature post exercise may possibly be explained by counter current heat exchange within vascular bundles of the leg. Blood flow to the arteries in the calf region post exercise would deliver warm blood from the core with heat most likely being transferred to the adjacent and cooler blood in the veins leaving the calf. The arterial blood would therefore be cooled, which on delivery to the cutaneous circulation of the leg would result in a decrease in skin temperature. Consequently flow and nutrient supply can be restored without any increase in limb temperature.

\section{CONCLUSION}

The results of this study suggest a redistribution of blood from the relatively inactive lower body during arm exercise of intensities up to $60 \% \mathrm{~W}_{\text {peak }}$ after which point calf volume does not significantly decrease further. Calf blood flow immediately at the end of exercise was greater than that at rest. The most likely explanation is that at the end of exercise rapid vasodilation occurred in the calf causing an increase in blood flow thus calf volume returned to baseline levels within 5 minutes of exercise ceasing. The calf volume decrease is therefore likely a result of vasoconstriction reducing blood pooling in the leg due to an increase in muscle sympathetic nerve activity. Reducing the venous pooling that is occurring during upper body exercise could substantially improve upper body exercise performance and may benefit sports which have a large upper body component such as kayaking.

Future research should focus upon the differentiation between calf muscle and calf skin blood flow during and following arm exercise, and the effects of longer durations of arm exercise on calf volume and skin temperature in order to examine further the thermoregulatory responses during upper body exercise.

4. Ho, C.W., Beard, J.L., Farrell, P.A., Minson, C.T., \& Kenney, W.L. (1997). Age, Fitness, and Regional Blood Flow During Exercise in the Heat. Journal of Applied Physiology, 82(4), 1126-1135.

5. Hopman, M.T., Verheijen, P.H., \& Binkhorst, R.A. (1993). Volume Changes in the Legs of Paraplegic Subjects During Arm Exercise. Journal of Applied Physiology, 75(5), 2079-2083.

6. Johnson, J.M., \& Rowell, L.B. (1975). Forearm Skin and Muscle Vascular Responses to Prolonged Leg Exercise in Man. Journal of Applied Physiology, 39(6), 920-924.

7. Johnson, J.M., Taylor, W.F., Shepherd, A.P., \& Park, M.K. (1984). Laser-Doppler Measurement of Skin Blood Flow: Comparison With Plethysmography. Journal of Applied Physiology, 56(3), 798-803 
8. Mitchell, J.W. (1977). Energy Exchanges During Exercise. In: Nadel E.R. (ed) Problems with temperature regulation during exercise (pp. 1126). New York: Academic Press.

9. Nadel, E.R., Cafarelli, E., Roberts, M.F., \& Wenger, C.B. (1979). Circulatory Regulation During Exercise in Different Ambient Temperatures. Journal of Applied Physiology, 46(3), 430437.

10. Price, M.J., \& Campbell, I.G. (1997). Thermoregulatory Responses of Paraplegic and Able Bodied Athletes at Rest and During Prolonged Upper Body Exercise and Passive Recovery. European Journal of Applied Physiology and Occupational Physiology, 76(6), 552-560.

11. Price, M.J., \& Campbell, I.G. (2002). Thermoregulatory Responses During Prolonged UpperBody Exercise in Cool and Warm Conditions. Journal of Sports Science, 20(7), 519-527.

12. Rowell, L.B., Blackmon, J.R., \& Bruce, R.A. (1964). Indocyanine Green Clearance and Estimated Hepatic Blood Flow During Mild to Maximal Exercise in Upright Man. Journal of Clinical Investigation, 43, 1677-1690.

13. Rowell, L.B., Blackmon, J.R., Martin, R.H., Mazzarella, J.A., \& Bruce, R.A. (1965). Hepatic Clearance Of Indocyanine Green In Man Under Thermal And Exercise Stresses. Journal of Applied Physiology, 20(3), 384-394.

14. Rowell, L.B. (1974). Human Cardiovascular Adjustments to Exercise and Thermal Stress. Physiological Reviews, 54(1), 75-159.

15. Saito, M., Tsukanaka, A., Yanagihara, D., \& Mano, T. (1993). Muscle Sympathetic Nerve Responses to Graded Leg Cycling. Journal of Applied Physiology,75(2), 663-667.
16. Saumet, J.L., Kellogg, D.L.,Jr., Taylor, W.F., \& Johnson, J.M. (1988). Cutaneous Laser Doppler Flowmetry: Influence of Underlying Muscle Blood Flow. Journal of Applied Physiology, 65(1), 478-481.

17. Sawka, M.N., Gonzalez, R.R., Drolet, L.L., \& Pandolf, K.B. (1984). Heat Exchange During Upper- and Lower-Body Exercise. Journal of Applied Physiology, 57(4), 1050-1054.

18. Sawka, M.N. (1986) 'Physiology of Upper Body Exercise. Exercise and Sport Sciences Reviews, 14, 175-211.

19. Seals, D.R. (1989). Sympathetic Neural Discharge and Vascular Resistance During Exercise in Humans. Journal of Applied Physiology, 66(5), 2472-2478.

20. Smith, P.M., Price, M.J., \& Doherty, M. (2001). Influence of Crank Rate on Peak Oxygen Consumption During Arm Crank Ergometry. Journal of Sports Science, 19(12), 955-960.

21. Smolander, J., Kolari, P., Korhonen, O., \& Ilmarinen, R. (1987). Skin Blood Flow During Incremental Exercise in a Thermoneutral and a Hot Dry Environment. European Journal of Applied Physiology and Occupational Physiology, 56(3), 273-280.

22. Theisen, D., Vanlandewijck, Y., Sturbois, X., \& Francaux, M. (2001a). Cutaneous Vascular Response and Thermoregulation in Individuals With Paraplegia During Sustained Arm-Cranking Exercise. International Journal of Sports Medicine, 22(2), 97-102.

23. Theisen, D., Vanlandewijck, Y., Sturbois, X., \& Francaux, M. (2001b). Central and Peripheral Haemodynamics in Individuals With Paraplegia During Light and Heavy Exercise. Journal of Rehabilitation Medicine, 33(1), 16-20. 


\title{
ЕФЕКТИ ИНТЕНЗИТЕТА ВЕЖБАҢА НА ОБИМ ЛИСТА НОГЕ И ТЕРМОРЕГУЛАЦИОНЕ РЕАКЦИЈЕ ТОКОМ ВЕЖБАЫА ГОРЊЕГ ДЕЛА ТЕЛА
}

\section{Сажетак}

Током вежби за горњи део тела испоставило се да васкуларна адаптација ноге игра важну терморегулациону улогу. Ово истраживање проучава ефекте интензитета вежбања на терморегулацију током вежби за горњи део тела. Девет здравих испитаника мушког пола били су подвргнути инкременталном тесту вежбања на ергометру зглоба руке како би се одредио врхунац снаге $\left(\mathrm{W}_{\text {peak }}\right)$. Испитаници су извели четири експерименталне пробе које су укључиле 5 минута вежби за руку на $45,60,75$, или $90 \% \mathrm{~W}_{\text {peak }}\left(70\right.$ рев.мин $\left.{ }^{-1}\right)$, након тога је следило 30 минута пасивног опоравка. Бележене су температуре ушног канала и коже, као и проток топлоте у надлактици и листу. Обим листа је мерен помоћу плетисмографије за време вежбања. Током вежбе на 45, 60, 75 и 90\% $\mathrm{W}_{\text {peak }}$ обим листа је смањен $(\mathrm{P}<0,05)$ за $-0,7 \pm 0,8,-1,4 \pm 0,9,-1,2 \pm 0,6$ односно $-1,6 \pm 0,7 \%$. Примећене су разлике између 45 и $60 \% \mathrm{~W}_{\text {peak }}$, и 45 и $90 \% \mathrm{~W}_{\text {peak }}(\mathrm{P}<0,05)$. Резултати ове студије указују на прерасподелу крви из релативно неактивног доњег дела тела током вежбе за руку при интензитету до $60 \% \mathrm{~W}_{\text {peak }}$, након чега даље се значајно не смањује обим листа. Дакле, прерасподела крви из неактивног доњег дела тела не производи реакцију сличног интензитета у зависности од унутрашњег протока крви током вежби за доњи део тела.
\end{abstract}

КљУчне речи: ЕРГОМЕТРИЈА ЗГЛОБА РУКЕ / ПРОТОК КРВИ / ТЕМПЕРАТУРА ЛИСТА / ТЕРМОРЕГУЛАЦИЈА / ИНТЕНЗИТЕТ ВЕЖБАЮА

\section{УВОД}

Током вежбе умереног интензитета за доњи део тела у хладним условима повећава се проток крви кроз кожу (Johnson \& Rowell, 1975), што заузврат повећава топлотни градијент између коже и атмосфере. Повећан градијент обезбеђује топлоту за преношење, излучивање и испаравање зноја, што омогућава побољшану размену топлоте (Rowell, 1974). За разлику од тога, током вежби за горњи део тела у хладним условима, показало се да обим листа опада (Hopman, Ferhaifen \& Binkhorst, 1993), што указује на то да се артеријски проток крви у листу смањује. Ову чињеницу подржава и пад температуре коже листа током продуженог вежбања горњег дела тела
(Price \& Campbell, 1997; 2002). Због тога се сугерише да се проток крви у листу прерасподељује на активни горњи део тела током вежби за руке (Hopman, Ferhaifen \& Binkhorst, 1993). Показало се да се ова прерасподела крви јавља током вежбе за доњи део тела из неактивног ткива и да повећа рад срчаног мишића и снабдевање крвљу мишиће који учествују у вежбању (Ho et al., 1997;. Sawka, 1986; Ahlborg \& Felig, 1982). Сходно томе, активни мишићи добијају већи проценат рада срчаног мишића, док унутрашњи органи тела добијају мањи (Sawka, 1986; Rowell, Blackmon \& Bruce, 1964; Rowell et al., 1965.). 
Током вежбе за доњи део тела, примећено је да се проток крви коже подлактице, која се често користи за представљање кожног протока крви целог тела (Johnson \& Rowell, 1975), линеарно повећава са температуром једњака (Smolander et al., 1987; Nadel et al., 1979) до интензитета вежбања од $80 \% \mathrm{BO}_{2 \max }$. Након ове тачке однос се смањује без даљег повећања протока крви у кожи (Smolander et al., 1987.). Исти однос није нађен при вежбању горњег дела тела и реакцији доњег дела тела. Посебно истраживање је показало смањење обима листа (представљеног протоком крви кроз кожу, мишиће и кости) током 10 минута вежбања за горњи део тела на $50 \% \mathrm{~W}_{\text {peak}}$, што сугерише смањење протока крви у листу (Hopman, Verheifen \& Binkhorst, 1993). Међутим, мало је тога познато у вези са променама у обиму листа при распону интензитета вежбања и потенцијалним реакцијама протока крви кроз кожу током вежбе за горњи део тела. Сакупљање крви у доњем делу тела потенцијално би могло да изазове терморегулационе проблеме и проблеме у кардиоваскуларној стабилности током вежбе за горњи део тела. Како се повећава интензитет вежби и долази до потребе за повећаним протоком крви у активне мишиће и кожу, биће потребна већа прерасподела крви из неактивних мишића. Ако се сакупљање крви јави у доњем делу тела то би могло изазвати повећано топлотно напрезање тела. Сходно томе, указано је на то да васкуларне адаптације ноге током вежбе за горњи део тела играју значајну физиолошку и, још конкретније, терморегулациону улогу током вежбе за горњи део тела, али то тек треба да буде у потпуности испитано (Price \& Kempbel, 1997).

Током вежбе за доњи део тела, промене у унутрашњем протоку крви зависе од интензитета (Rowel, 1974), а могуће је да приказана смањења у обиму листа можда такође приказују исту реакцију зависности од интензитета. Успостављање терморегулационих реакција у доњем делу тела људи без инвалидитета током вежбе за горњи део тела при различитом интензитету вежбања помоћи ће да се успостави терморегулациони модел који би могао да помогне у будућим препорукама за вежбе за особе са, на пример, повредама кичмене мождине или мултиплекс склерозе. Дакле, главни циљ овог истраживања је био да се испита ефекат интензитета вежбања на промене у обиму листа током вежбе за горњи део тела да би се испита- ла прерасподела крви током вежбања горњег дела тела. Претпоставило се да ће се, при повећању интензитета вежбе, смањити обим листа.

\section{МЕТОД}

\section{Испитаници}

Девет испитаника мушког пола (просечне старости 22,9 $\pm 3,6$ година, тежине 78,4 $\pm 13,7$ кг) генерално, али не и посебно “истренирани” у горњем делу тела, добровољно су се јавили да учествују у истраживању. Прибављено је уверење Етичког одбора Универзитета за експерименталне процедуре истраживања уз писмени пристанак обавештеног пацијента и поштовани су принципи наведени у Хелсиншкој декларацији.

\section{Прелиминарни тестови}

Испитаници субилиприсутни улабораторији у пет наврата. Током прве посете, испитаници су извели тест инкременталног вежбања коришћењем ергометра зглоба руке са електронском кочницом (Lode, Angio, Groningen, Netherlands), како би се одредио врх апсорпције кисеоника $\left(\dot{\mathrm{V}}_{2 \text { peak }}\right)$ и врх излазне снаге $\left(\mathrm{W}_{\text {peak }}\right)$. Ово друго је коришћено за одређивање интензитета вежби за свако следеће експериментално испитивање. Након десет минута хлађења, испитаници су упознати са четири различита интензитета вежби које је требало извести у наредне четири посете.

$\dot{\mathrm{V}} \mathrm{O}_{\text {2реak }}$ сваког испитаника је одређен помоћу инкременталног испрекиданог протокола вежбе (Smith, Price \& Doerti, 2001). Испитаници су седели са раменима у истој линији са осом лакта на ергометру. Њихова стопала су била постављена водоравно на поду у металним држачима како би се осигурало да зглоб колена буде под углом од $90^{\circ}$. Протокол се састојао од четири четвороминутне фазе субмаксималне вежбе (30, 50, 70 односно 90W) са два минута одмора између фаза. Ипитаници су били у обавези да одрже каденцу од 70 рев.мин ${ }^{-1}$ током вежбе. Након последње фазе од четири минута и периода одмоpa, протокол се повећавао за 20W свака два минута од $110 \mathrm{~W}$ до вољног замора, или до тренутка када су учесници могли да одрже 70 рев.мин ${ }^{-1}$. 
Ботомс Л.М., Прајс М.Ј., Ефекти интензитета вежбања... ФИЗИЧКА КУЛТУРА 2011; 65 (1): 5-15

Континуирано су праћени издахнути гас (Metamax 3B, Leipzig, Germany) и учесталост рада срца (HR; Polar Accurex Plus, Kempele, Finland).

\section{Субмаксимални тестови}

Све “тест вежбе” су вршене на температури простора од 20,5 $\pm 1,4^{\circ} Ц$ и $63,8 \pm 5,8 \%$ влажности. Испитаници су дошли у лабораторију после два сата паузе у узимању хране и уздржавања од напорног вежбања током претходних 24 сата. Испитивање је спроведено као кросовер (crossover) дизајн. Сваки испитаник је тестиран у четири наврата са најмање три дана паузе између сваке пробе. Пробе су се састојале од 5 минута вежбе за руку на $45,60,75$ или $90 \%$ од $\mathrm{W}_{\text {peak }}$, чему је следило 30 минута пасивног опоравка.

По доласку у лабораторију, телесна маса је забележена помоћу ваге за мерење телесне тежине (Seca, Hamburg, Germany). Испитаници су носили шортс, чарапе и патике и одмарали су се 15 минута док им нису постављени терморезистори и сензори. Терморезистори за ушни канал и кожу су у континуитету снимани преко записивача података (Squirrel 1020 series, Cambridge, UK). Температура уха је мерена ушним терморезистором (Grant, Cambridge, UK) уметнутим у слушни канал испитаника, и сигурно причвршћеном траком на одговарајућем месту с изолованом ватом. Терморезистори за кожу (Grant, Cambridge, UK) били су причвршћени на стандардна анатомска обележја за надлактицу, леђа, груди, бутину и лист. Додатни терморезистор је постављен на други прст десне ноге пошто је скинута патика и чарапа. Терморезистори су причвршћени за кожу уз помоћ водопропусне траке (3M Transpore, Loughborough, $\mathrm{UK})$. Средња температура коже ( $\left.\mathrm{T}_{\mathrm{ms}}\right)$ израчуната је помоћу Раманатанове једначине (1964) где је: $\mathrm{T}_{\mathrm{ms}}$ $=0,3\left(\mathrm{~T}_{\text {chest }}\right)+0,3\left(\mathrm{~T}_{\text {upper arm }}\right)+0,2\left(\mathrm{~T}_{\text {calf }}\right)+0,2\left(\mathrm{~T}_{\text {thigh }}\right)$. Топлотни ток је мерен на листу и надлактици помоћу сензора протока топлоте (Data Harvest Easy Sense Advanced, Bedfordshire, UK) и био је стално бележен. Сензори су причвршћени у близини терморезистора за кожу на листу и надлактици и били су причвршћени водопропусном траком у складу са упутством произвођача.

Током сваке субмаксималне пробе континуирано је анализиран издахнути гас. Полазни подаци за сва мерења су добијени током одмора при седењу од пет минута пре вежбања, а узорак

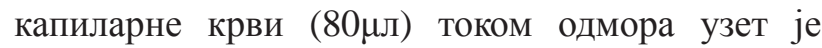

из ушне шкољке за мерење крвног лактата (Analox GM7, London, UK). Примењена je плетисмографија опсега напрезања за мерење релативне промене обима листа током вежбе за руку. Проток крви потколенице је мерен у стању мировања коришћењем плетисмографије венске оклузије и стандардних процедура (Норman, Verheifen \& Binkhorst, 1993). Плетисмограф опсега напрезања (Hokanson EC6, Bellevue, USA) састојао се од две цеви од силиконске гуме испуњене живом, постављене око најдебљег дела, левог листа, причвршћен траком у одговарајућем положају. Обликована трака за мерење крвног притиска је стављена на леву бутину, одмах изнад колена, и повезана са брзом ваздушном пумпом за траку (Hokanson E20, Bellevue, USA), подешена на надувавање до 50ммХг за пет секунди и испумпавање за осам секунди. Плетисмограф је био прикључен на персонални рачунар преко Powerlab (AD Instruments, Chalgrove, UK) и онлајн снимци су приказани кроз Chart4windows. Коришћено је у просеку три надувавања за одређивање протока крви у сваком одређеном тренутку времена.

Испитаници су изводили вежбу за лакат руке 5 минута на 70 рев.мин ${ }^{-1}$ на насумице задат интензитет вежбе. Температуре топлотног тока и коже бележене су сваког минута у току и по престанку вежбања. Промене у обиму листа од одмора су бележене током вежбања. $\mathrm{RPE}_{\text {central }}$ и $\mathrm{RPE}_{\text {local }}$ забележени су 30 секунди пре престанка вежбања. Унос кисеоника ( $\mathrm{V} \mathrm{O}_{2}$ ), размена гасова у минуту (VE) и однос респираторне размене (RER) су израчунавани као просек у последњих 30c сваког минута у току вежбања и у интервалима од пет минута током 30 минута пасивног опоравка. Проток крви је забележен у миру и по престанку вежбања. Одмах после вежбе узет је још један узорак капиларне крви из ушне шкољке за мерење крвног лактата. Испитаници су тада остали да седе 30 минута због опоравка. Топлотни ток, проток крви, аурална и температура коже бележене су на сваких 5 минута пасивног опоравка. Телесна маса је бележена пре и после вежбања да би се израчунао губитак због знојења.

\section{Статистичка анализа}

Сви подаци су анализирани преко Минитаб верзије 14,0. Подаци су анализирани варијансом двосмерне анализе (време $\mathrm{x}$ интензитет) са 
поновљеним мерењима. Тамо где је добијена значајна разлика, урађен је Такијев пост хок тест. Извршена је одговарајућа Пирсонова корелација да се испитају неузрочне везе између променљивих варијабли, нпр. крвног лактата насупрот RPE. Подаци су представљени као аритметичка средина \pm SEM у бројкама, и аритметичка средина \pm с у табелама. Значајност је узета као $\mathrm{P}<0,05$.

\section{РЕЗУЛТАТИ}

\section{Прелиминарни тестови}

Врхунац физиолошких реакција добијених у току инкременталног теста за $\dot{\mathrm{V}} \mathrm{O}_{\text {2реak }}$ приказан је у табели 1.

Табела 1: Аритметичка средина $( \pm \mathrm{CД})$ физиолошке реакције добијене током инкременталног $\mathrm{O}_{2 \text { peak }}$ теста $(\mathrm{n}=9)$

\begin{tabular}{|c|c|}
\hline & $\mathrm{AC}( \pm \mathrm{C}$ Д) \\
\hline$\dot{\mathrm{V}} \mathrm{O}_{2 \text { peak }}\left(\mathrm{l} \cdot \mathrm{min}^{-1}\right)$ & $2.21( \pm 0.59)$ \\
\hline$\dot{\mathrm{V}} \mathrm{O}_{\text {2peak }}\left(\mathrm{ml} \cdot \mathrm{kg}^{-1} \cdot \mathrm{min}^{-1}\right)$ & $28.6( \pm 7.1)$ \\
\hline $\mathrm{HR}_{\text {peak }}$ (откуцаја/ $\mathrm{min}^{-1}$ ) & $184( \pm 12)$ \\
\hline $\mathrm{W}_{\text {peak }}(\mathrm{W})$ & $124( \pm 24)$ \\
\hline E (l.min-1) & $73.9( \pm 16.7)$ \\
\hline $\mathrm{Bla}_{\text {peak }}\left(\mathrm{mmol} \mathrm{l}^{-1}\right)$ & $7.33( \pm 1.34)$ \\
\hline Однос респираторне размене & $1.17( \pm 0.09)$ \\
\hline $\mathrm{RPE}_{\text {central }}$ (Боргова скала) & $18( \pm 2)$ \\
\hline $\mathrm{RPE}_{\text {local }}($ Боргова скала) & $19( \pm 1)$ \\
\hline
\end{tabular}

\section{Физиолошке реакције током вежбања и пасивног опоравка}

Физиолошке реакције на престанак сваке субмаксималне пробе вежбе за руку приказане су у табели 2. Разлика између интензитета вежбања је праћена и за $\mathrm{HR}$ и $\dot{\mathrm{V}} \mathrm{O}_{2}$ током вежбања и опоравка (главни ефекат; $P<0,05$ ). Током пасивног опоравка, HR је смањен али је остао већи $(P<0,01)$ него опоравак у свим, осим у покушају $45 \% \mathrm{~W}_{\text {peak }}$. Крвни лактат је растао линеарно са интензитетом вежбања $(P<0,05)$. Телесна маса се смањила у свим покушајима $(-0,1 \pm 0,1,-0,2 \pm 0,1,-0,1 \pm 0,1$ и $-0,1 \pm 0,1 \kappa г$ за $45,60,75$ односно $90 \% \mathrm{~W}_{\text {peak }}$ ) без значајне разлике између покушаја $(P<0,05)$.

Табела 2: Аритметичка средина (АС) и стандардана девијација ( \pm СД) физиолошког одговора на престанак субмаксималне пробе вежбе за руку $(\mathrm{n}=9)$

\begin{tabular}{|c|c|c|c|c|c|}
\hline$\% \mathrm{~W}_{\text {peak }}$ & $\underset{\left(1 . \mathrm{min}^{-1}\right)}{\dot{\mathrm{V}}}$ & $\begin{array}{c}\text { Срчана } \\
\text { фреквенција } \\
\text { (откуцаја } / \mathrm{min}^{-1} \text { ) }\end{array}$ & $\begin{array}{c}\text { Лактати у крви } \\
\left(\text { mmol. } l^{-1}\right)\end{array}$ & $\begin{array}{c}\mathrm{RPE}_{\text {централни }} \\
\text { (Боргова скала) }\end{array}$ & $\begin{array}{c}\mathrm{RPE}_{\text {локални }} \\
\text { (Боргова скала) }\end{array}$ \\
\hline $45 \%$ & $1.16 \pm 0.15 *$ & $112 \pm 12 *$ & $3.0 \pm 0.6 *$ & $10 \pm 1$ * & $11 \pm 2 *$ \\
\hline $60 \%$ & $1.46 \pm 0.21 *$ & $128 \pm 10 *$ & $5.0 \pm 1.2 *$ & $12 \pm 1 *$ & $14 \pm 1 *$ \\
\hline $75 \%$ & $1.72 \pm 0.31 *$ & $154 \pm 12 *$ & $6.7 \pm 0.8 *$ & $14 \pm 1$ * & $15 \pm 1 *$ \\
\hline $90 \%$ & $2.09 \pm 0.49 *$ & $170 \pm 18 *$ & $8.1 \pm 1.0 *$ & $16 \pm 1 *$ & $18 \pm 2 *$ \\
\hline
\end{tabular}

*3начајност $(P<0.05)$ главног ефекта изумеђу интензитета вежбе 


\section{Аурална температура током вежбе и пасивног опоравка}

Главни ефекат интензитета вежбања је примећен за ауралну температуру $(P<0,05)$. Post hос анализа је показала разлику између 45 и 90\% $\mathrm{W}_{\text {peak }}$ покушаја и, 60 и 90\% $\mathrm{W}_{\text {peak }}$ покушаја. На крају вежбе у свим покушајима аурална температура се смањена са вредности током одмора за $-0,04 \pm 0,21,-0,03 \pm 0,20,-0,13 \pm 0,08$ и $-0,14 \pm$ $0,24^{\circ} \mathrm{C}$ за $45,60,75$, односно $90 \%$.

\section{Температура коже горњег дела тела током вежбе и пасивног опоравка}

Температура коже надлактице се у почетку смањила током првог минута вежбања $(P<0,05$; слика 1). Одмах после вежбања температура коже надлактице порасла је у свим тестовима $(P<0,05$; главни ефекат за време). Постојао је главни ефекат за интензитет вежбе са већим порастом температуре који се десио током тестова високог интензитета (75 и 90\% $\mathrm{W}_{\text {peak }}$ ) у поређењу са тестовима слабијег интензитета (45 и 60\% $\mathrm{W}_{\text {peak }}$ ). Главни ефекат за време је примећен $(P<0,05)$ за температуру груди која се смањила за време вежбања коме је следила наредна вежба за све покушаје. Није било разлика између интензитета вежбе за температуру груди $(P<0,05)$. Температура коже леђа је остала релативно константна током вежбања и пасивног опоравка за сваки интензитет вежбе $(P<0,05)$.

Слика 1: Аритметичка средина ( \pm СД) релативне промене температуре коже надлактице током сваког теста вежбе на 45, 60, 75 и 90\% $\mathrm{W}_{\text {peak }}$ и пасивног опоравка (n=9). EX означава период вежбања.

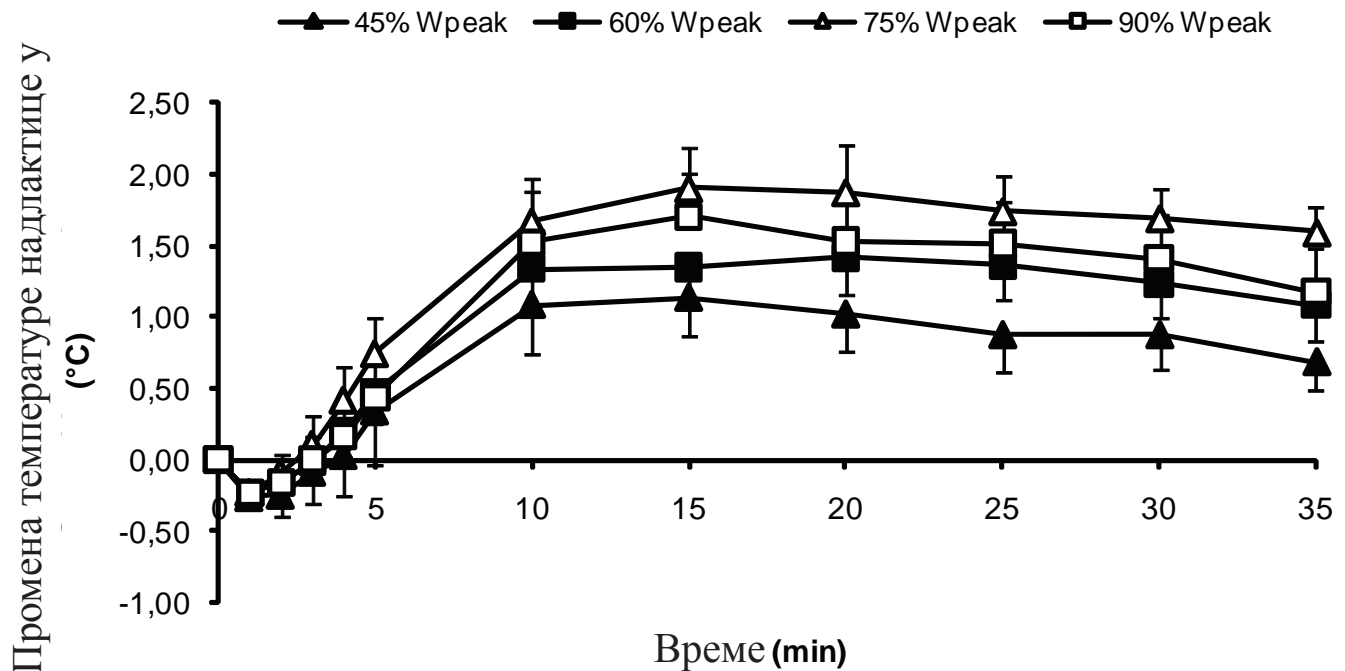

\section{Температура коже доњег дела тела током вежбе и пасивног опоравка}

Температура коже бутине се смањила за време вежбања и пасивног опоравка (главни ефекат за време $P<0,05)$. Разлике су посматране између тестова 60 и 75\% W $\mathrm{W}_{\text {peak }}, 60$ и 90\% $\mathrm{W}_{\text {peak }}$ (главни ефекат за интензитет; $P<0,05)$. Током вежбе температура листа је остала константна, међутим, током опоравка температура листа је смањена у свим тестовима $(P<0,05)$, са већим смањењем температуре током опоравка у односу на вежбање високог интензитета (75 и 90\% $\mathrm{W}_{\text {peak }}$, слика 2) када се упо- реди са нижим интензитетима (главни ефекат за интензитета; $P<0,05)$. Температура коже листа се смањила за 1,0 \pm 0,6, 0,9 $\pm 0,3,1,0 \pm 0,3$, односно $1,0 \pm 0,5^{\circ} \mathrm{C}$ током $45,60,75$ и $90 \% \mathrm{~W}_{\text {peak }}$ после 30 минута за опоравак, односно $(P<0,05)$. Температура ножног прста је остала константна током вежбе, и одмах се повећала током пасивног опоравка $(P<0,05)$. Значајна разлика између интензитета вежбања је примећена између 45 и 60\% $\mathrm{W}_{\text {peak}}$, 60 и $75 \% \mathrm{~W}_{\text {peak }}$, и 60 и $90 \% \mathrm{~W}_{\text {peak }}$. 
Слика 2: Аритметичка средина ( \pm SEM) релативне промене температуре коже листа током сваког теста вежбе на 45, 60, 75 и 90\% $\mathrm{W}_{\text {peak }}$ и пасивног опоравка (n=9). ЕХ означава период вежбања.

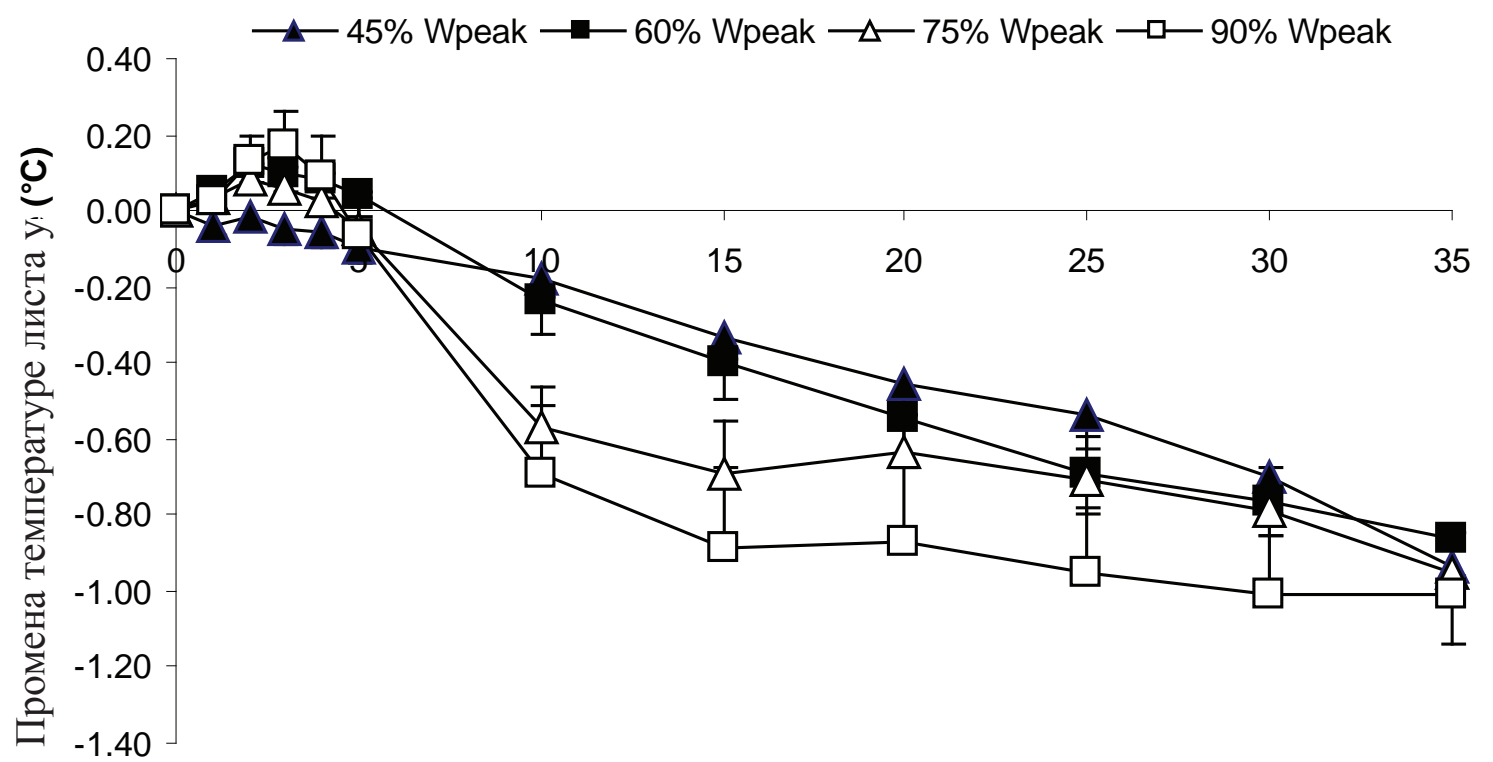

Време: (min)

\section{Просечна температуре коже}

Просечне температуре коже добијене у овом раду су биле сличне у мировању $(30,6 \pm 0,9$, $30,6 \pm 0,5,30,3$ и $30,5 \pm 1,1 \pm 1,1^{\circ}$ Ц за 45,60 , 75 односно $90 \% \mathrm{~W}_{\text {peak }}$ ) у односу на оне на крају вежбања у свим тестовима $(30,5 \pm 0,9,30,6 \pm 0,8$, $30,4 \pm 1,4$ односно $\left.30,2 \pm 1,5^{\circ} \mathrm{C}\right)$.

\section{Проток топлоте током вежбе и пасивног одмора}

Проток топлоте из надлактице повећан је од мировања за време првог минута вежбе (повећан за $27 \pm 13,21 \pm 7,26 \pm 13$ и $29 \pm 16 \mathrm{~W} \cdot \mathrm{M}^{-2}$ за 45 , 60, 75, односно $90 \% \mathrm{~W}_{\text {peak }}, P<0,05$; слика 3a).
Међутим, постојала је тенденција даљег повећања протока топлоте током вежбања, али не значајно у било ком покушају. Са престанком вежбања проток топлоте се смањио $(P<0,05)$ и остао је константан током пасивног опоравка. Проток топлоте током вежбања и опоравка на $90 \% \mathrm{~W}_{\text {peak }}$ био је већи од остала три интензитета $(P<0,05)$. Нису забележене друге разлике између проба. За разлику од надлактице, проток топлоте од листа је остао константан током вежбања и пасивног опоравка при свим интензитетима вежбања $(P<0,05$; слика 3б). Међутим, проток топлоте је био нижи током $45 \% \mathrm{~W}_{\text {peak }}$ када се упореди са остала три интензитета у мировању и током вежбања и пасивног опоравка (главни ефекат за интензитет; $P<0,05$ ). 
Слика 3. Аритметичке средине (АC) мерења протока топлоте за а) надлактицу b) лист на 45, 60, 75 и $90 \% \mathrm{~W}_{\text {peak }}(\mathrm{n}=9)$.
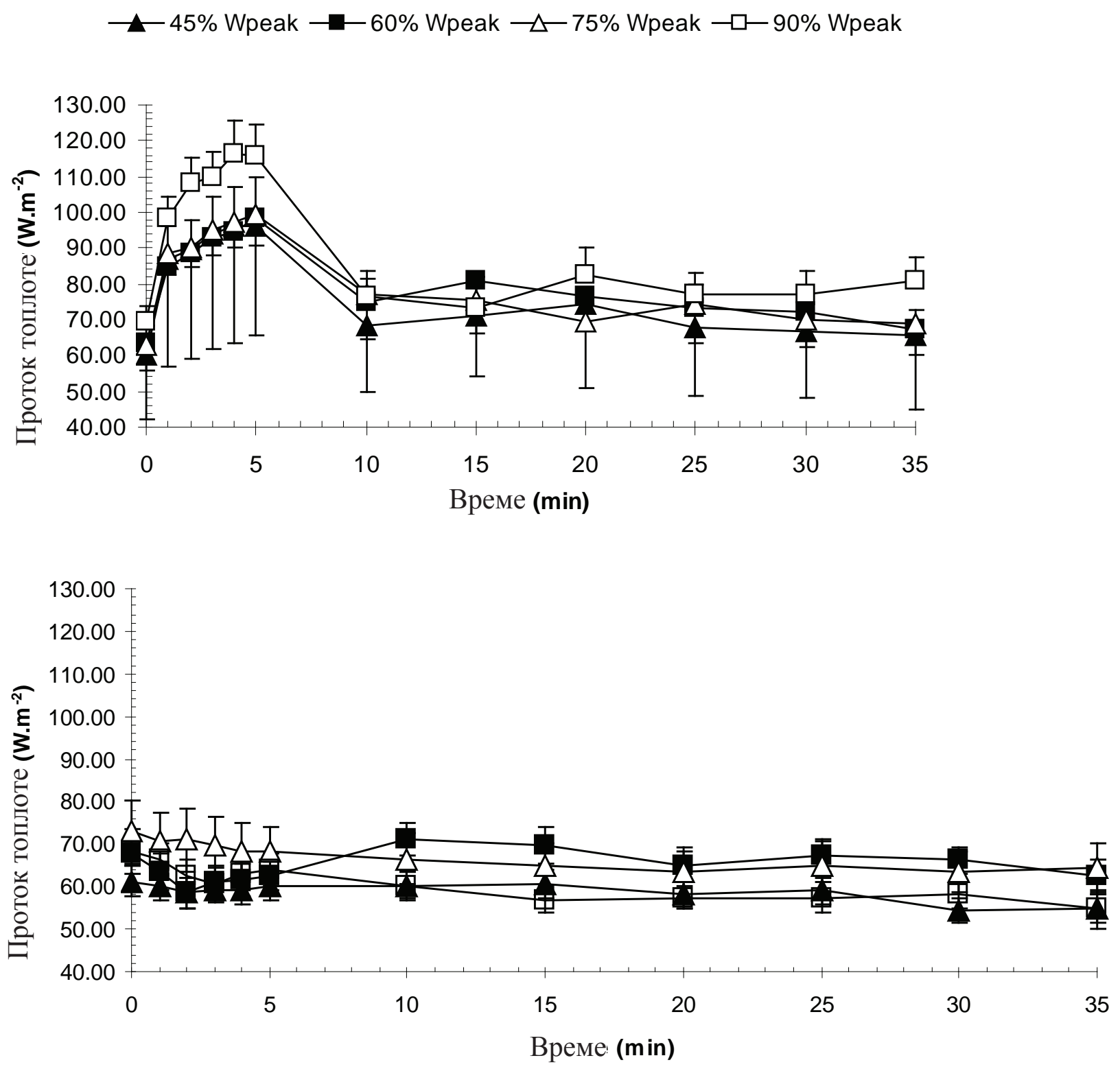

\section{Обим листа и проток крви током вежбе и пасивног одмора}

Када се упореди са мировањем, обим листа се смањио $(P<0,05)$ током вежбања при сваком интензитету вежбе $(-0,7 \pm 0,8,-1,4 \pm 0,9,-1,2$ $\pm 0,6$, односно -1,6 $\pm 0,7 \%$; Слика 4). Разлике су посматране између $45 \%$ и $60 \% \mathrm{~W}_{\text {peak }}$, и 45 и $90 \%$ $\mathrm{W}_{\text {peak }}(\mathrm{P}<0,05)$. Обим листа се вратио на основну вредност у року од пет минута пасивног опорав- ка у свим тестовима. Вредности протока крви су биле највеће на крају вежбе у поређењу са одмором $(1,32 \pm 0,52,1,91 \pm 0,58,2,11 \pm 0,81$ односно, $1,76 \pm 0,68$ мл.мин ${ }^{-1} .100$ мл $\left.^{-1}, P<0,05\right)$ вративши се на основну вредност током пасивног опоравка $(1,32 \pm 0,36,1,36 \pm 0,47,1,63 \pm 0,74$ односно 1,38 \pm 0,55 мл.мин ${ }^{-1} .100$ мл $\left.^{-1}\right)$ за сваку пробу. Прво мерење протока крви листа био је значајно веће од другог и трећег мерења (главни ефекат за време; $P<0,05)$. Постојао је такође и главни ефе- 
кат за покушај, са протоком крви који је био знатно нижи у $45 \% \mathrm{~W}_{\text {peak }}$ тесту у односу на друге те- стове $(P<0,05)$, без иједне друге разлике која се десила $(P<0,05)$.

Слика 4. Процентуална промена у обиму листа током вежбања сваком од интензитета вежбања.

* приказује значајност разлика $(\mathrm{P}<0.05)$ код $45 \%$ интензитета

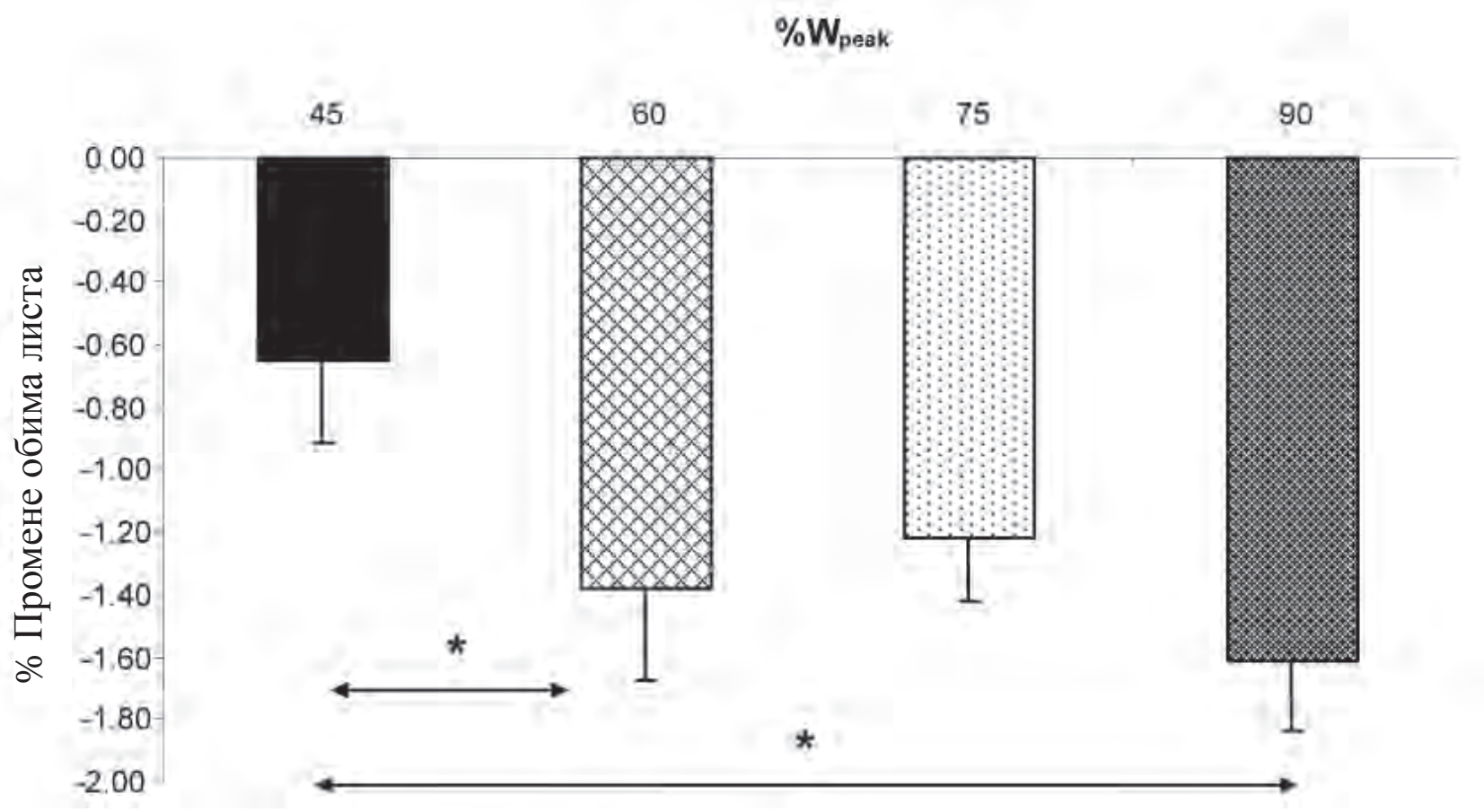

\section{ДИСКУСИЈА}

Главни циљ истраживања је био да се утврди утицај интензитета вежбања на обим листа помоћу мерача напрезања плетисмографа као средства испитивања прерасподеле крви током вежбе за руке. Главно откриће истраживања је смањење обима листа током вежбе при интензитетима до $60 \% \mathrm{~W}_{\text {peak }}$ после те тачке се обим листа није даље значајно смањивао. Ово смањење обима листа било је праћено повећањем протока крви у листу од мировања до краја вежбе.

\section{Терморегулационе реакције горњег дела тела}

Током првих 5 минута пасивног опоравка дошло је до значајног пораста температуре коже руке у свим тестовима због смањења конвективне струје ваздуха и, као последица, смањења протока топлоте руке. 75 и $90 \% \mathrm{~W}_{\text {peak }}$ тестови показали су веће повећање температуре коже руке, највероватније због веће метаболичке производње топлоте од тестова 40 и $60 \% \mathrm{~W}_{\text {peak }}$. Сходно томе, већа локална акумулација топлоте се вероватно десила пошто би промене у конвективним ваздушним струјама биле исте за сваки покушај (тј. све вежбе изведене истом брзином кретања, 70рев.мин $\left.{ }^{-1}\right)$. С друге стране, почетни пад температуре руке током вежбања се вероватно десио због повећаног протока топлоте, као резултат конвекције тренутног генерисања на започињање покрета (Mitchell, 1977).

Савка и сар. (Sawka et al., 1984) сугеришу да су вредности протока топлоте репрезентативни за проводљивост коже и због тога пружају релативни индекс протока крви у кожи. Дакле, мора да се у овом истраживању проток крви у надлактицу повећао на основу повећаног протока топлоте. Апсолутни проток топлоте руке је био сличан за тестове 45, 60 и 75\%, али је већи за тест 90\%, што сугерише већи пораст протока крви у кожи за вежбе већег интензитета. То може да представља интензитет вежбања где је директни пренос топлоте већи са мишића који је у контракцији. Заиста, ако проток топлоте стварно представља про- 
Ботомс Л.М., Прајс М.Ј., Ефекти интензитета вежбања... ФИЗИЧКА КУЛТУРА 2011; 65 (1): 5-15

ток крви коже (Sawka et al., 1984) онда би то дозволио већи пренос топлоте из надлактице на окружење у тесту $90 \%$ што као резултат има сличан апсолутни пораст температуре коже при другим тестовима.

\section{Терморегулациое реакције доњег дела тела}

Смањење обима листа је примећено током свих интензитета вежбања, међутим, после $60 \% \mathrm{~W}_{\text {peak }}$ није примећено даље смањење. Хопман, Верхајфен и Бинкхорст (Hopman, Verheifen \& Binkhorst, 1993) су мерили обим листа током 10 минута вежбе за руке на 50\% $\mathrm{W}_{\max }$ и приметили су смањење у обиму од $0,1 \%$ у минути за 5 минута вежби, што је иста стопа смањења у обиму екстремитата у минути као током теста $45 \% \mathrm{~W}_{\text {peak }}$ у овом истраживању. Међутим, садашње истраживање је проширило ове податке тиме што је примећено да пад обима листа није линеаран са интензитетом вежбања, и стога не изражава исто смањење у зависности од интензитета као висцерални проток крви. То би највероватније било због тога што било које даље смањења протока крви ногу са већим интензитетом вежбања резултира релативно малим протоком који може довести у питање испоруку кисеоника у доње екстремитете. Највероватнија улога вазоконстрикције листа током почетних фаза вежбе је да се помогне одржавање кардиоваскуларне стабилности.

За разлику од резултата ове студије, Тејсен и сар. (Theisen et al., 2001a; 2001б) су приметили да се у току вежбе за руке на $50 \% \mathrm{~W}_{\text {peak }}$ и $80 \%$ $\mathrm{W}_{\text {peak }}$ проток крви кроз кожу листа повећао током вежбања. Ови аутори мерили су проток крви кожу користећи ласерски доплер мерач протока који мери проток крви само до 1,5 мм испод коже (Johnson et al., 1984). Дакле, смањење обима листа је примећено у овом истрживању коришћењем плетисморафије, што може бити претежно последица смањења протока крви кроз мишиће, а не протока крви до површинских слојева коже (Saumet et al., 1988.). То је подржао Силс (Seals, 1989) који је сугерисао да ће се током вежбања стиска шаке провећати приток крви кроз кожу, а проток крви до мишића листа ће се смањити.

Иако је дошло до смањења у обиму листа за време вежбања, није било значајне разлике у температури листа или протока топлоте у листу. У претходном истраживању (Price \& Kempbel, 1997) примећено је смањење температуре листа током вежбања, али као што је раније поменуто, трајање вежбе било је знатно дуже (60-90 минута). Претпостављено је у овом случају да је до пада температуре листа током продуженог вежбања руку при сталном интензитету вежби $\left(60 \% \dot{\mathrm{V}} \mathrm{O}_{2 \text { peak }}\right)$ и температуре околине дошло због смањеног протока крви у лист. Пошто је лист релативно метаболички неактиван током вежбе за горњи део тела, можда је потребно дуже трајање вежбања да би се десиле значајне промене у температури коже листа због смањења протока крви и промена у термалним стању. Зато би испитивање односа између обима листа и температуре током дужег трајања вежбе допринело нашем разумевању односа протока крви у листу и температуре коже.

Запремина листа је одмах почела да се враћа у правцу првобитног стања чим је престала вежба чиме се сугерише да се враћа проток крви до мишића. Ово би можда могло да се објасни брзом вазодилатацијом у листу која се десила одмах по престанку вежбања што је изазвало брз пораст протока крви (хиперемиа) у лист. Током овог истраживања примећено је да се обим листа смањио током вежбања, што се највероватније десило због повећане симпатичке нервне активности мишића (Saito et al., 1993) изазивајући вазоконстрикцију у листу. Чим је престала вежба десила се брза вазодилатација услед чега је дошло до наглог пораста протока крви у листу како се крв враћала у лист. Ово је показала и чињеница да је проток крви био највећи на првом мерењу после тренига у односу на друго и треће мерење; међутим, то се догодило само у тестовима 75 и $90 \% \mathrm{~W}_{\text {peak }}$. Симпатичка нервна активност мишића (MSHA) зависи од вежбе (Saito et al., 1993), па је стога MSHA довољна само током вежбања у тестовима 75 и $90 \% \mathrm{~W}_{\text {реаk }}$ да изазове ову брзу хиперемију кад се вежба завршила. Проток крви се смањио према основним вредностима за остатак пасивног опоравка, након овог иницијалног повећања.

Неколико студија је утврдило да су просечан обим листа и резултати варирали између 1,7 - 3,4 л (Hargens, 1983; Convertino et al., 1989, Moore \& Thornton, 1987). Стога коришћење овог приближ- 
ног обима и количине крви која се преусмерава од листа приликом вежбе за горњи део тела у овој студији може бити процењена. Обим листа се смањио између $0,7-1,6 \%$ током вежбања у свим студијама што се изједначава са количином од око 12-54 мл крви која је преусмерена из листа. Дакле, резултати показују да доњи део тела изгледа има мали допринос не само на терморегулацију, већ и на кардиоваскуларну стабилност.

Смањење температуре коже листа после вежби се евентуално може објаснити "супротном разменом топлоте” у васкуларном ткиву ноге. Проток крви у артерије у региону листа после вежби би испоручио топлу крв из срца са топлотом која се највероватније преноси на суседну и хладнију крв у венама које излазе из листа. Артеријска крв ће се стога хладити, што ће на пренос у кожну циркулацију ноге резултирати смањењем температуре коже. Због тога се проток крви и снабдевање хранљивим материјама може поново успоставити без повећања температуре у екстремитету.

\section{ЗАКЉУЧАК И ПРАКТИЧНА ПРИМЕНА}

Резултати овог истраживања указују на прерасподелу крви из релативно неактивног доњег дела тела током вежбе за руку при интензитету до $60 \% \mathrm{~W}_{\text {peak }}$ после чега се обим листа више не смањује значајно. Одмах по завршетку вежбе је проток крви у листу био већи него у мировању. Највероватније објашњење је да се на крају вежбе догодила брза вазодилатација у листу што је изазивало повећање протока крви, чиме је обим листа враћен на основни ниво у року од 5 минута по престанку вежбе. Смањење обима листа је стога вероватно последица вазоконстрикције која је смањила сакупљање крви у нози због повећања симпатичке нервне активности у мишићу. Смањење венског сакупљања крви које се дешава током вежбе за горњи део тела могу значајно побољшати перформансе вежбања горњег дела тела и од тога могу имати користи спортови који имају компоненте великог горњег дела тела као што је веслање кајака.

Будућа истраживања би требало да се усредсреде на разлику између мишића листа и протока крви у кожи листа за време и након вежбе за руке, као и на утицаје дужег трајања вежбе за руке на обим и температуру коже листа у циљу даљег испитивања терморегулационих реакција током вежби за горњи део тела.

3. Hargens, A.R., Tipton, C.M., Gollnick, P.D., Mubarak, S.J., Tucker, B.J., \& Akeson, W.H. (1983). Fluid Shifts and Muscle Function in Humans During Acute Simulated Weightlessness. Journal of Applied Physiology, 54(4), 10031009.

4. Ho, C.W., Beard, J.L., Farrell, P.A., Minson, C.T., \& Kenney, W.L. (1997). Age, Fitness, and Regional Blood Flow During Exercise in the Heat. Journal of Applied Physiology, 82(4), 1126-1135.

5. Hopman, M.T., Verheijen, P.H., \& Binkhorst, R.A. (1993). Volume Changes in the Legs of Paraple- 
gic Subjects During Arm Exercise. Journal of Applied Physiology, 75(5), 2079-2083.

6. Johnson, J.M., \& Rowell, L.B. (1975). Forearm Skin and Muscle Vascular Responses to Prolonged Leg Exercise in Man. Journal of Applied Physiology, 39(6), 920-924.

7. Johnson, J.M., Taylor, W.F., Shepherd, A.P., \& Park, M.K. (1984). Laser-Doppler Measurement of Skin Blood Flow: Comparison With Plethysmography. Journal of Applied Physiology, 56(3), 798-803

8. Mitchell, J.W. (1977). Energy Exchanges During Exercise. In: Nadel E.R. (ed) Problems with temperature regulation during exercise (pp. 1126). New York: Academic Press.

9. Nadel, E.R., Cafarelli, E., Roberts, M.F., \& Wenger, C.B. (1979). Circulatory Regulation During Exercise in Different Ambient Temperatures. Journal of Applied Physiology, 46(3), 430437.

10. Price, M.J., \& Campbell, I.G. (1997). Thermoregulatory Responses of Paraplegic and Able Bodied Athletes at Rest and During Prolonged Upper Body Exercise and Passive Recovery. European Journal of Applied Physiology and Occupational Physiology, 76(6), 552-560.

11. Price, M.J., \& Campbell, I.G. (2002). Thermoregulatory Responses During Prolonged UpperBody Exercise in Cool and Warm Conditions. Journal of Sports Science, 20(7), 519-527.

12. Rowell, L.B., Blackmon, J.R., \& Bruce, R.A. (1964). Indocyanine Green Clearance And Estimated Hepatic Blood Flow During Mild To Maximal Exercise In Upright Man. Journal of Clinical Investigation, 43, 1677-1690.

13. Rowell, L.B., Blackmon, J.R., Martin, R.H., Mazzarella, J.A., \& Bruce, R.A. (1965). Hepatic Clearance Of Indocyanine Green In Man Under Thermal And Exercise Stresses. Journal of Applied Physiology, 20(3), 384-394.

14. Rowell, L.B. (1974). Human Cardiovascular Adjustments to Exercise and Thermal Stress. Physiological Reviews, 54(1), 75-159.
15. Saito, M., Tsukanaka, A., Yanagihara, D., \& Mano, T. (1993). Muscle Sympathetic Nerve Responses to Graded Leg Cycling. Journal of Applied Physiology,75(2), 663-667.

16. Saumet, J.L., Kellogg, D.L.,Jr., Taylor, W.F., \& Johnson, J.M. (1988). Cutaneous Laser Doppler Flowmetry: Influence of Underlying Muscle Blood Flow. Journal of Applied Physiology,65(1), 478-481.

17. Sawka, M.N., Gonzalez, R.R., Drolet, L.L., \& Pandolf, K.B. (1984). Heat Exchange During Upper-and Lower-Body Exercise. Journal of Applied Physiology,57(4), 1050-1054.

18. Sawka, M.N. (1986) 'Physiology of Upper Body Exercise. Exercise and Sport Sciences Reviews, 14, 175-211.

19. Seals, D.R. (1989). Sympathetic Neural Discharge and Vascular Resistance During Exercise in Humans. Journal of Applied Physiology, 66(5), 2472-2478.

20. Smith, P.M., Price, M.J., \& Doherty, M. (2001). Influence of Crank Rate on Peak Oxygen Consumption During Arm Crank Ergometry. Journal of Sports Science, 19(12), 955-960.

21. Smolander, J., Kolari, P., Korhonen, O., \& Ilmarinen, R. (1987). Skin Blood Flow During Incremental Exercise in a Thermoneutral and a Hot Dry Environment. European Journal of Applied Physiology and Occupational Physiology, 56(3), 273-280.

22. Theisen, D., Vanlandewijck, Y., Sturbois, X., \& Francaux, M. (2001a). Cutaneous Vascular Response and Thermoregulation in Individuals With Paraplegia During Sustained Arm-Cranking Exercise. International Journal of Sports Medicine, 22(2), 97-102.

23. Theisen, D., Vanlandewijck, Y., Sturbois, X., \& Francaux, M. (2001b). Central and Peripheral Haemodynamics in Individuals With Paraplegia During Light and Heavy Exercise. Journal of Rehabilitation Medicine, 33(1), 16-20. 